\title{
Recent Advancements in Field of Medicinal Plant Research With special reference to Acne Therapy
}

\author{
Review Article
}

\section{Shyam Baboo Prasad1, Srinivasan Marimuthu², Prasad G P3*, Mangal A K ${ }^{4}$, Srikanth $\mathbf{N}^{5}$}

\author{
1. Research officer (Pharmacognosy), 2. Research officer (Bio-Chemistry), 3. Assistant Director Incharge, \\ Regional Ayurveda Institute for Fundamental Research, Pune. \\ 4. Assistant Director (Pharmacognosy), 5. Deputy Director General, \\ Central Council for Research in Ayurvedic Sciences, New Delhi.
}

\begin{abstract}
Acne is an exclusive disease associated with skin occurs when sebaceous glands attain special conditions at face, chest and back in the pre pubertal child. This disease occurs in both male and female, there is no preference among them but the course is more severe in males. Though, there are several treatment methods to treat acne, no particular medication claims a satisfactory and complete remedy. A wide range of synthetic therapeutic agents have also been reported to treat acne but have severe adverse effect. Medicinal plants by virtue of their safe nature and easy availability may lend themselves as potential anti-acne therapy. The present review deals with the proven medicinal plants to treat acne.
\end{abstract}

Key Words: Acne, Acne therapy, Propionibacterium acnes, Medicinal plant etc.

\section{Introduction}

Medication and cosmetic measures to overcome skin problems continue to be a foremost research and development initiates by pharmaceutical, cosmeceutical and personal care industries. Herbal medicines with the history of use from ancient time have entered the growing 'cosmeceutical' market for combating various skin problems (1). It is attracting renewed attention from both practical and scientific view even though the mode of action of phyto-constituents from herbal origin is more complex than mechanisms of one bioactive factor. Ancient records show that herbal approaches are proven to be effective for primary health care and treatment of various diseases (2).

Skin is most important and sensitive part of the human body. The external environmental exposure leads to many kinds of skin problems and disorders like acne, sunburn and pigmentation (1). Acne is common skin disorder encountered in the age group of 15-25 years owing to increased production of sebum followed by the attack of Propionibacterium acnes. It usually

\section{* Corresponding Author:}

\section{Prasad G P}

Assistant Director Incharge,

Regional Ayurveda Institute for Fundamental Research, Pune.

Email id-drprasadgoli@yahoo.com begins at puberty and worsens during adolescent age, usually early $12-13$ years in females and 14-16 years in males. It has been estimated to effect $90 \%$ males and $85 \%$ females at teenage (3). Statistic study revealed that globally around $85 \%$ of young adults aged 12-25 aged old, $8 \%$ of adult aged 25-34 years old, 3\% of adults aged 35-44 years old experienced certain degree of acne and in the age of twenty, both men and women continuous suffered by acne with $42.5 \%$ and50.9\% respectively. Recent research shows that, around $30 \%$ of women with their fertile period faced persistent acne (4). One population study in Germany shows that $64 \%$ of aged 20 to 29 years old and $43 \%$ of aged 30 to 39 years old have visible acne and another study of more than 2000 adults found that $3 \%$ of men and $5 \%$ of women still have definite mild acne at the age of 40 to 49 years (5). In USA, $61.9 \%$ of patients aged 18 years and older were seen in clinics for acne (6). Due to hormonal changes $99.5 \%$ of teenage boys and $83 \%$ of teenage girls are affected by acne (7).

Natural alternatives are blooming as they are being explored for healing multiple factors related with acne (8). Topical approach is useful in treatment of acne whereas it can also be effectively used for deramatophytosis, candidiasis, Tinea nigra and fungal keratitis (9). Natural products research play important role in the identification of bioactive lead molecule for the management of acne (4). The plants producing antioxidant, antimicrobial, anticomedogenic activity 
and in certain cases hormone balancing properties can be beneficial as acne involve production of free radicals in inflammatory conditions, microorganism invasion and hormone imbalance. But still there is need for comprehensive studies of combining various herbs which can help people at preliminary stages of acne and other skin diseases $(10,11)$.

\section{Etiology}

It includes increased sebum production influenced by hormone, altered follicular keratinisation, immune hypersensitivity, oxidative stress, inflammation and bacterial (Propionibacterium acnes) colonisation on the face, neck, chest, and back (4). The factors that are involved in the pathogenesis of acne are inter-connected with each other (12). Acne is mainly characterized by seborrhoea, inflammatory lesions, non-inflammatory lesions and degrees of scarring (5). The higher density of their occurrence depends upon the amount of oil glands present on body part and most areas affected are face, neck, shoulders, upper chest and back (13). There are different micro-organisms which are responsible for outbreak of acne. Propionibacterium acnes is the main causative organisms, Staphylococcus epidermidis and Malassezia furfur are also present in acne lesions (14). Propionibacterium acne is an anaerobic micro-organism which is part of normal skin flora and Staphylococcus epidermidis is aerobic microorganism which take participate in superficial infection within pilosebaceous unit (15). Increased sebum production by sebaceous gland provides the growth medium for P.acne that are responsible for inflammation and oedema by secreting chemo tactic factors like substance along with lipolytic and proteolytic enzymes (10). M. furfur is lipophilic yeasts that mainly found in the skin diseases like pityriasis versicolor, pityriasis capitis, and folliculitis (16-18).

\section{Pathogenesis of acne:}

Pathogenesis of acne involves multiple factors which further worse the condition of acne. At the age of puberty, the androgen concentration increases which ultimately leads to the increase sebum production (18). Composition of sebum mainly consist mixture of lipid, wax, squalene and cholesterol that normally provide the barrier to the skin. Hormonal effects ultimately alter the sebaceous gland function and sebum composition, particularly Linoleic acid (13). Due to increase amount of sebum, the hair follicles get plugged. These plugged hair follicle containing anaerobic lipid-rich environment which provides a growth medium for P. acnes (10). P.acne is a member of normal flora on skin that multiplies in clogged hair follicles (19). It is responsible for release of lipase that metabolise sebaceous triglycerides into free fatty acids which are highly chemo tactic and lead to the production of various cytokines like IL-8 and IL-1a which lead to inflammation. Depending on conditions, the lesion may be inflammatory or non-inflammatory (open or closed comedones, papule, pustule or nodule) (20).

\section{Treatment of acne}

Aim of treatment of acne is:

- Antibacterial, anti-inflammatory, anti-oxidant activity.

- Decreasing the excess sebum production

- Correcting altered follicular keratinisation.

- Decreasing P. acne population. (19)

\section{Synthetic approach}

There are several medications used for its treatment from which topical preparations like creams, ointments, and gels are common. Other oral hormonal, oral antibiotics and antibacterial medications may be prescribed for severity cases. History and cause of acne is important factor of identification before its treatment (11).These agents have impact on the pathogenetic factors and chosen according to type of acne lesions (21).Various approach for combating acne is as follow:

- Topical and oral retinoid E.g. (Tritinoin and isotretinoin)

- Topical antimicrobials. E.g. (Erythromycin and clindamycin)

- Oral antibiotics E.g. (tetracycline's and macrolides)

- Keratolytics E.g. (Azaleic acid)

- Hormonal therapy that include oral contraceptives as well as androgen blocking agents. E.g. (cyproterone acetate and ethinyloestradiol) (4).

For many years, antibiotic and retinoid have been used in treatment of acne vulgaris but these drugs produce a number of side effects and develop multifactorial resistance due to irrational use of antibiotics (1). Drugs like Benzoyl peroxide, antiandrogens, and antibiotics are exhibiting several side effects after withdrawal (3).

\section{Herbal approach}

Synthetic agents are accompanied by various side effects like itching, redness, skin peeling, stinging, photosensitivity and drug resistance. Therefore herbal approaches which have negligible adverse effects compared with allopathic medicine are commonly indicated for moderate to severe form of acne. These herbal agents possessed not only the antimicrobial activity but they also exhibit the antioxidant, antiinflammatory activity. Various Herbs have skin detoxifying property which is consider as good source for the treatment of acne (1). There are some Indian medicinal plants used in the treatment of acne vulgaris that are listed below: 
International Journal of Ayurvedic Medicine, Vol 11 (1), 10-14

Table no: 1

\begin{tabular}{|c|c|c|c|c|c|c|}
\hline Plant & $\begin{array}{l}\text { Common } \\
\text { Name }\end{array}$ & Family & Part in use & Active compound & Activity & References \\
\hline $\begin{array}{l}\text { Cosinium fenestratum } \\
\text { (Gaertn.) Colebr. }\end{array}$ & Jhar-i-hald & Menispermaceae & Extract & Alkaloid & Antibacterial & $(22)$ \\
\hline Arctium lappa $\mathrm{L}$. & Burdock & Asteraceae & Extract & Arctiopicrin & $\begin{array}{c}\text { Anti- } \\
\text { inflammatory }\end{array}$ & $(23)$ \\
\hline $\begin{array}{l}\text { Azadirachta indica A. } \\
\text { JUSS. }\end{array}$ & Neem & Meliaceae & Aerial part & Azadirachtin & Antibacterial & (24) \\
\hline $\begin{array}{c}\text { Eucalyptus globules } \\
\text { LABILL }\end{array}$ & Safeda & Myrtaceae & Extract & $\alpha$-pinene, $\beta$-pinene & Antibacterial & $(25)$ \\
\hline Ammania baccifera L. & Dadamari & Lytharaceae & Extract & $\beta$-sitosterol & Antibacterial & (26) \\
\hline Berberis vulgaris L. & Kasmal & Berberidaceae & Root & Berberine & Antibacterial & (27) \\
\hline Berberis aristata DC. & Daruharidra & Berberidaceae & Stem & Berberine & Antiacne & (3) \\
\hline Curcuma longa $\mathrm{L}$. & Haldi & Zingiberaceae & Root & Curcumine & $\begin{array}{c}\text { Anti- } \\
\text { inflammatory }\end{array}$ & (28) \\
\hline $\begin{array}{l}\text { Hemidesmus indicus } \\
\text { (L.) SCHULT. }\end{array}$ & Anantamul & Apocynaceae & Root & Coumarine & Antioxidant & (24) \\
\hline Carica papaya L. & Papita & Caricaceae & Seeds, peel & Enzymes & Antioxidant & (29) \\
\hline $\begin{array}{l}\text { Coleus forskohlii } \\
\text { ANDR. }\end{array}$ & Gandira & Labiatae & Extract & Essential oil & Antibacterial & (30) \\
\hline $\begin{array}{l}\text { Cymbopogon citrates } \\
\text { (DC.) STAPF. }\end{array}$ & Aghyaghas & Poaceae & Leaves & Essential oil & Antibacterial & (31) \\
\hline $\begin{array}{c}\text { Lonicera japonica } \\
\text { Thunb. }\end{array}$ & Madhumathi & Caprifoliaceae & Flower & flavonoids & Antibacterial & $(32)$ \\
\hline Ocimum sanctum L. & Tulsi & Lamiaceae & Oil & Eugenol & Antibacterial & (33) \\
\hline Allium cepa $\mathrm{L}$. & Piyaj & Alliaceae & Bulb & Flavonoids & $\begin{array}{c}\text { Anti- } \\
\text { inflammatory }\end{array}$ & (1) \\
\hline Eclipta alba HASSK. & Bharangi & Asteraceae & Extract & Wedololactone & Antibacterial & (34) \\
\hline $\begin{array}{c}\text { Pterocarpus santalinus } \\
\text { L.F. }\end{array}$ & $\begin{array}{l}\text { Rakta- } \\
\text { chandana }\end{array}$ & Fabaceae & $\begin{array}{l}\text { Leaves } \\
\text { stems }\end{array}$ & Sesquiterpenes & Antibacterial & $(35)$ \\
\hline $\begin{array}{c}\text { Terminalia arjuna } \\
\text { (ROXB.) WIGHT \& } \\
\text { ARN. }\end{array}$ & Arjun & Combretaceae & Bark & Tannin & Antibacterial & (36) \\
\hline Cocos nucifera $\mathrm{L}$. & Nariyal & Arecaceae & Nut & Fatty acids & $\begin{array}{c}\text { Anti- } \\
\text { inflammatory }\end{array}$ & (37) \\
\hline Nigella sativa L. & Kalajira & Ranunculaceae & Flowers & & $\begin{array}{c}\text { Anti- } \\
\text { inflammatory }\end{array}$ & (38) \\
\hline Calendula officinalis L. & Zendu & Asteraceae & Extract & Glycosides & Antibacterial & (39) \\
\hline Glycyrrhiza glabra L. & Mulathee & Fabaceae & Rhizomes & $\begin{array}{l}\text { Flavonoids, } \\
\text { saponin }\end{array}$ & Antibacterial & $(40)$ \\
\hline $\begin{array}{c}\text { Saraca asoka (ROXB.) } \\
\text { DE WILDE }\end{array}$ & Ashoka & Caesalpiniaceae & Extract & Tannin & Antibacterial & $(41)$ \\
\hline Rubia cordifolia L. & Manjith & Rubiaceae & Root & & Antioxidant & $(42)$ \\
\hline Curcurbita pepo L. & Kadimah & Curcurbitaceae & Extract & Linoleic acid & $\begin{array}{l}\text { Anti- } \\
\text { inflammatory }\end{array}$ & (43) \\
\hline Plumbago zeylanica L. & Chitarak & Plumbaginaceae & Extract & $\begin{array}{l}\text { Naphthoquinones } \\
\text { Polyphenolics } \\
\text { compounds, } \\
\text { Plumbagin }\end{array}$ & Antibacterial & $\begin{array}{l}(44) \\
(11)\end{array}$ \\
\hline Plumbago indica L. & Lal-Chitrak & Plumbaginaceae & $\begin{array}{l}\text { Acetone } \\
\text { extract, } \\
\text { Plumbagin }\end{array}$ & $\begin{array}{l}\text { Naphthoquinones } \\
\text { Polyphenolics } \\
\text { compounds } \\
\text { Plumbagin }\end{array}$ & Antiacne & $(9-10)$ \\
\hline Piper longumL. & Pipli & Piperaceae & Extract & $\begin{array}{l}\text { Phenolic } \\
\text { compounds }\end{array}$ & Antioxidant & $(45)$ \\
\hline $\begin{array}{c}\text { Tephrosia pupurea } \\
\text { PERS. }\end{array}$ & Biyani & Menispermiaceae & Extract & Sesquiterpene & Antioxidant & (46) \\
\hline $\begin{array}{c}\text { Tinospora cordifolia } \\
\text { (WILLD.) HOOK.F. \& } \\
\text { THOMS. }\end{array}$ & Giloe & Menispermiaceae & Extract & Alkaloids & Antioxidant & $(47)$ \\
\hline Santalum album L. & Chandan & Santalaceae & wood & Santalons & Antibacterial & (1) \\
\hline Arnica Montana L. & Arnica & Asteraceae & $\begin{array}{c}\text { Dried } \\
\text { flower head }\end{array}$ & Sesquiterpenes & $\begin{array}{c}\text { Anti- } \\
\text { inflammatory }\end{array}$ & $(48,49)$ \\
\hline Vitex negundo L. & Nirgundi & Verbenaceae & Extract & Terpenoids & Antioxidant & $(50)$ \\
\hline Juglans nigra L. & $\begin{array}{c}\text { Black } \\
\text { walnut }\end{array}$ & Juglandaceae & Leaves & Tannins & Antibacterial & (1) \\
\hline
\end{tabular}




\begin{tabular}{|c|c|c|c|c|c|c|}
\hline \multicolumn{8}{|c|}{ Shyam Baboo Prasad et.al., Role of Phytomedicine In Acne Therapy } \\
\hline $\begin{array}{c}\text { Phyllanthus emblica } \\
\text { GAERTN. }\end{array}$ & Amla & Phyllantheaceae & Extract & Tannin & Antioxidant & (4) \\
$\begin{array}{c}\text { Quercus infectoria Oliv. } \\
\text { Zingiber cassumunar } \\
\text { Roxb. }\end{array}$ & $\begin{array}{c}\text { Majuphal } \\
\text { Cassumunar } \\
\text { ginger }\end{array}$ & Fagaceae & Extract & Tannin & Antioxidant & (46) \\
\hline $\begin{array}{c}\text { Camellia sinensis (L.) } \\
\text { O.KUNTZE }\end{array}$ & Chha & Theaceae & Extract & Uronic acids & Antibacterial \\
\hline
\end{tabular}

\section{Conclusion}

Natural remedies are more acceptable in the belief that they are safer with fewer side effects than the synthetic ones. So, herbal anti-acne solution which is non-toxic, safe, effective, and improves patient compliance by the utilisation of herbal extracts / isolated constituent would be highly acceptable.

\section{Conflict of interest: Nil}

\section{References}

1. Kapoor S, Saraf S, Topical herbal therapies an alternative and complementary choice to combat acne. Res. J. Med. Plant 2011; 5;650-669

2. Pandey M, Debnath M, Gupta S, Chikara S.K, Phytomedicine: An ancient approach turning into future potential source of therapeutics. J Pharmacog Phytotherapy 2011; 3; 27-37.

3. Prasad S.B, Kaur D. In Vitro Anti Acne Activity of Ethanolic Extract of Stem of Berberis aristata. Int. J. Pharmacog. Phytochem. Res. 2017;9(2);190-192.

4. Sinha P, Srivastava S, Mishra N, Prasad Y.N, New Perspectives on Antiacne Plant Drugs: Contribution to Modern Therapeutics. BioMed Res Int. 2014; 1; 19.

5. Prasad S.B, Acne vulgaris: A review on pathophysiology and treatment. Asian J. Pharm. and Clin. Res. 2016; 9 (4); 54-59.

6. Yentzer B.A, Hick J, Reese E.L, Uhas A, Feldman S.R., Balkrishnan R. Acne vulgaris in the united states: a descriptive epidemiology. Cutis 2010;86;94-99

7. Dey P, Karuna D.S, Bhakta T, Medicinal Plants used as Anti-Acne Agents by Tribal and Non-Tribal People of Tripura, India. 2014;2(5):556-70.

8. Yarnell E, Abascal K. Herbal medicine for acne vulgaris. Alternative \& Complementary Therapies. 2006 Dec 1;12(6):303-9.

9. Kaur D, Prasad S.B, Verma S, Formulation and Evaluation Gel from Extract of Plumbago indica for Acne. Int. J. Drug. Del. Tech. 2016;6(3):95-98.

10. Kaur D, Prasad S.B, Anti-acne activity of acetone extract of plumbago indica root. Asian Journal of Pharmaceutical and Clinical Research. 2016; 9(2):285-287.

11.Azimi H, Fallah-Tafti M, Khakshur AA, Abdollahi M. A review of phytotherapy of acne vulgaris: Perspective of new pharmacological treatments. Fitoterapia. 2012 Dec 1;83(8):1306-17.

12. Abbasi M.A, Kausar A, Rehman AU, Saleem H, Jahangir S.M, Siddiqui S.Z, Ahmad V.U., Preparation of new formulations of anti-acne creams and their efficacy. African J. Pharm. Pharmacol. 2010; 4:298.
13.Balakrishnan K. P, Narayanaswamy N, Subba P, Poornima E. H., Antibacterial activity of certain medicinal plants against acne-inducing bacteria. Int. J. Pharm. Bio Sciences. 2011; 2:477-481.

14.Prasad S.B, Bist M, In vitro anti acne activity of methanolic extract of dried fruit of Embelia ribes. Int J Pharm Qualty Assurance. 2018 Oct 16;9(1):90-94.

15.Choi J.S, Bae HJ, Kim SJ, Choi IS, In vitro antibacterial and antiinflammatory properties of seaweed extracts against acne inducing bacteria, Propionibacterium acnes. J. Environmental Bio. 2011; 32;313-318.

16.Crespo M.J, Abarca M.L, Cabanes FJ,.Isolation of Malassezia furfur from a cat. Journal of Clinical Microbiology. 1999; 37; 1573.

17.Abbasi M.A, Kausar A, Rehman A.U, Saleem H., Jahangir S.M, Siddiqui SZ, Ahmad VU, Preparation of new formulations of anti-acne creams and their efficacy. African J.Pharm. Pharmacol. 2010;4;298-303.

18.Prasad S.B, Kaur D, Formulation of Topical Gel from Extract of Berberis aristata DC for Acne. Int. J. Drug Del. Tech. 2019 9; 9(01);104-108.

19.Priyanka M, Patidar A, Gupta D, Agrawal S, 2010. Treatment of Acne with Herbal Remedies Calendula officinalis: An Overview. Int. J. Pharm. Bio. Archives 2010; 2: 1020-1023.

20.Batubara I., Mitsunaga T., Ohashi H., Screening antiacne potency of Indonesian medicinal plants: antibacterial, lipase inhibition, and antioxidant activities. Journal Wood Sci 2009;55:230-235.

21.Ghosh V.K, Nagore D.H, Kadbhane K.P, Patil M.J, Different approaches of alternative medicines in acne vulgaris treatment. Oriental Pharmacy and Experimental Medicine 2011; 11:1-9.

22.Kumar G.S, Jayaveera K.N, Kumar A.C, Swamy B.M.V, Sanjay P.U, Kumar K.DV, Antibacterial screening of selected Indian medicinal plants against acne inducing bacteria. Pharmacologyonline 2007; 6: 717-723.

23.Hines $M$, Florence $\mathrm{T}$, Botanical anti-acne formulations.2013 (US/2013/ 8440237 /B2).

24.Jain A, Basal E, Inhibition of propionibacterium acnes-induced mediators of Inflammation by Indian herbs. Phytomedicine. 2003; 10:34-38.

25. Takahashi T, Kokubo R, Sakaino M, Antimicrobial activity of eucalyptus leaf extract and flavanoids from eucalyptus maculate. Lett appl microbial 2004;39:60-64.

26.Poornima V, Sharanya M, Jeyam M, An Ethnomedical, Pharmacological and Phytochemical review of Ammannia baccifera. World J Pharm. Res. 2014;3;1771-1789. 
27.Rohollah F, fouladi M.D, Aqueous Extract of Dried Fruit of Berberis vulgaris L. in Acne vulgaris, a Clinical Trial. . Journal of Dietary Supplements 2012;9:253-261.

28. Rasheed A, Kumar Reddy G.A, Mohanalakshmi N, Ashok kumar C.K, Formulation and comparative evaluation of poly herbal anti-acne face wash gels. Pharmaceutical Biology 2011;49;771-774.

29. Bezalwar P M, Gomashe A V, Gulhane P A, A quest of Anti-acne Potential of Herbal Medicines for extermination of MDR Staphylococcus aureus. Int. J. Pharm. Sci. Invention 2014; 3:12-17.

30. Majeed M, Gangadharan G.K, Prakash S, Compositions and methods containing high purity fatty alcohol C24 to C36 for cosmetic applications. US Patent, 2007 (US/2007/0196507/A1)。

31.Manosroi A, Chankhampan C, Jainonthee P, Manosroi J, Antiacne activity of the cream containing aromatic volatile oil from Thai Lanna medicinal plants entrapped in niosomes. J.Thai Traditional \& Alternative Med. 2008; 6 (2) 115-119.

32. Tsai T.H, Tsai T.H, Wu W.H, Tseng J.T.P, Tsai P.J, In vitro antimicrobial and anti-inflammatory effects of herbs against Propionibacterium acnes. Journal of Food Chemistry 2010;119; 964-968.

33. Sawarkar H.A, Khadabadi S.S, Mankar D.M, Farooqui I.A, Jagtap N.S, Development and Biological Evaluation of Herbal Anti-Acne Gel. Int. J. PharmTech 2010; 2;2028-2031.

34.Rani G.S, Gunda R.K, Mansa Y, Vardhan CH. K, Kumar V.D, Venkateswarlu G, Preparation and Evaluation of Antimicrobial and Antioxidant Activity of Polyherbal Ointment. Int. J. Current Trends Pharm. Res. J. 2015;3;997-1003.

35. Manjunatha B K. Antibacterial activity of Pterocarpus santalinus. Indian J Pharm Sci 2006; $68 ; 115-116$

36. Vijayalakshmi A, Tripura A, Ravichandiran V, Development and Evaluation of Anti-Acne Products from Terminalia Arjuna Bark. International Journal of ChemTech Research 2011; 3:320-327.

37. Sheshala R, Teck Ying L, Shiau Hui L, Barua A, Dua K. Development and anti-microbial potential of topical formulations containing Cocos nucifera Linn. Anti-Inflammatory \& Anti-Allergy Agents in Medicinal Chemistry (Formerly Current Medicinal Chemistry-Anti-Inflammatory and Anti-Allergy Agents). December 2013; 1;12(3):253-64.

38. Hadi N.A, Ashor A.W, Nigella Sativa Oil Lotion $20 \%$ vs. Benzoyl Peroxide Lotion $5 \%$ in the Treatment of Mild to Moderate Acne Vulgaris. The Iraqi Postgraduate Med. J. 2010;9;371-376.

39. Nand P, Drabu S, Gupta R.K, Phytochemical and antimicrobial screening of medicinal plants for the treatment of acne. Indian J. Nat. Prod. Resources 2010;3; 28-32.

40.Kanlayavattanakul M, Lourith N, Therapeutic agent and herbs in topical application for acne treatment. International J. Cosmetic Sci. 2011; 33;289-297.

41.Sruthi CV, Vendamirtham S, Maniyan A.K, Neeraj PT, Sunitha V, Sindhu A, An Exploratory Study on Asokarishtam an Ayurvedic Formulation with Leaves of Saraca Asoka. American J. PharmTech Res. 2014;4; 447-455.

42. Gorle A.M, Patil S.S, Evaluation of antioxidant and antiacne property of Rubia cordifolia. Der Pharmacia Sinica 2010; 1;59-63.

43.Chonoko U.G., Rufai A.B., Phytochemical Screening and Antibacterial Activity of Cucurbita pepo (Pumpkin) against Staphylococcus aureus and Salmonella typhi. Bayro J. Pure App. Sci. 2011;4;145-147.

44.Pant M, Lal A, Rana S, Rani. Plumbago zeylanica $\mathrm{L}$ : A mini review. Int. J. Pharm. App. 2012;3;399-405.

45. Yadav N, Singh A, Chatterjee A, Belemkar S, Evaluation of Efficacy and Safety of Perfact Face Gel and Perfact Face Tablets in Management of Acne. Clin. Exp. Derm. Res. 2011;2;1-7

46.Kumar G.S, Jayaveera K.N, Kumar A.C, Umachigi P Sanjay, Swamy BM Vrushabendra., Kumar D.V.K, Antimicrobial effects of Indian medicinal plants against acne-inducing bacteria. Tropical J. Pharm. Res. 2007; 6; 717-723

47.Mishra P, Jamdar P, Desai S, Patel D, Meshram D, Phytochemical analysis and assessment of in vitro antibacterial activity of Tinospora cordifolia. Int.J.Curr.Microbiol.App.Sci 2014; 3: 224-234.

48.James E.R, Tyler V.E, Herbs of Choice. The Haworth press, London: 219-223

49. Wagner S, Suter A, Merfort I, Skin penetration study of arnica preparation and their after Sesquiterpenes lactone. Planta Med. 2004; 70; 897-903

50.Dharmasiri M.G, Jayakody J.R, Galhena G, Liyanage S.S, Ratnasooriya W.D. Anti-inflammatory and analgesic activities of mature fresh leaves of Vitex negundo. Journal of ethnopharmacology. 2003 Aug 1;87(2-3);199-206.

51.Pithayanukul P, Tubprasert J, Wuthi-udomlert M, In vitro antimicrobial activity of Zingiber cassumunar (plai) oil and a $5 \%$ of plai oil gel. Phytother Res 2007; 21;164-169.

52.Lee J.H, Shim J.S, Chung M.S, Lim S.T, Kim K.H, In vitro anti-adhesive activity of green tea extract against pathogen adhesion. Phytotherapy Research. April 2009; 23 (4); 460-466. 